\title{
Are fears of an increase in casualization due to Covid-19 justified?
}

\author{
¿Están justificados los temores de un aumento de casualización debido a la Covid-19?
}

\author{
Jan Feyen iD \\ Professor Emeritus, Catholic University of Leuven, Belgium. \\ Corresponding author: jan.feyen@kuleuven.be
}

I am afraid that the answer to this question is YES. The impact of the pandemic on the economy will be tremendous. Just to give a small example, according to the Department of Labor and Employments of the Philippines (June 2020) went exactly 69,022 employees -from more than 2,000 establishments across the country- jobless. Unfortunately, this number does not include the small private businesses that went bankrupt as a consequence of the week-long lockdowns. And the same unfavorable picture holds for many countries. To illustrate the impact on the private sector, the second example is taken from Muskegon city in the U.S. state of Michigan, with a 2020 census population of 36,903 , the 30th largest city in Michigan. The city is proud to have the largest beach in West Michigan, a city rich with history, a high level of services, recreational opportunities, and spectacular shoreline, and a low cost of living. However, due to Covid-19 the recreational-based economy collapsed and with the winter just at the corner the need for assistance is increasing rapidly, and at this very moment, the number of Muskegon County residents facing hunger has risen to $20.6 \%$. The job loss that we witnessed so far has largely been temporarily, but permanent job loss is rising.

Will the education sector be immune from the financial debacle caused by Covid-19? The impact will be acute, universities in the United Kingdom, for example, has recognized serious financial challenges ahead and London Economics is indicating a potential sector-wide loss of tuition fees of 2.6 billion pounds next year. This will be hard for the private universities which mainly derive their income from registration fees and donations. However, the public universities will also be hit financially by Covid19 , since a lower-income at the national level will reduce the government's funding. With further pressure likely to land on research funding from public, charitable, and commercial sources, universities, in general, will be facing significant financial challenges ahead. To offset drops in government funding higher education institutions might, as a measure of cost-saving, stagnate or even decline the number of full-time permanent positions, and shift to casual or contract positions. Switching a tenure position to a contractual appointment will be juridical difficult, probably not possible. But it is not unlikely, that when full-time professors retire, the vacancies will be filled with a casual or contract position. Thus, it is to be expected that in the coming years the number of tenure positions in higher education will drop.
Me temo que la respuesta a esta pregunta es SÍ. El impacto de la pandemia en la economía será tremendo. Solo para dar un pequeño ejemplo, según el Departamento de Trabajo y Empleo de las Filipinas (junio de 2020) exactamente 69,022 empleados -de más de 2,000 establecimientos en todo el país- quedaron sin trabajo en medio de la crisis del coronavirus. Desafortunadamente, este número no incluye las pequeñas empresas privadas que quebraron como consecuencia de los cierres de emergencia de varias semanas. Y el mismo panorama desfavorable se aplica a muchos países. Para ilustrar el impacto en el sector privado, el segundo ejemplo se toma de la ciudad de Muskegon en el estado estadounidense de Michigan, con una población de 36,903 (censo 2020), la trigésima ciudad más grande de Michigan. La ciudad se enorgullece de tener la playa más grande de West Michigan, una ciudad rica en historia, un alto nivel de servicios, oportunidades recreativas, una costa espectacular y un bajo costo de vida. Sin embargo, debido a la Covid-19, la economía basada en la recreación colapsó y con el invierno a la vuelta de la esquina, la necesidad de ayuda está aumentando rápidamente y, en este mismo momento, el número de residentes del condado de Muskegon que sufren de hambre ha aumentado al $20.6 \%$. La pérdida de empleos que hemos presenciado hasta ahora ha sido en gran parte temporal, pero la pérdida permanente de empleos está aumentando.

¿Resultará inmune el sector de la educación a la debacle financiera causada por la Covid-19? El impacto será agudo, las universidades del Reino Unido, por ejemplo, han reconocido serios desafíos financieros por delante y London Economics indica una posible pérdida de ingresos por matrículas, en todo el sector, de 2,600 millones de libras el próximo año. Esto será muy difícil para las universidades privadas, que obtienen sus ingresos principalmente de cuotas de inscripción y donaciones. Sin embargo, las universidades públicas también se verán afectadas financieramente por la Covid-19, ya que un ingreso más bajo a nivel nacional reducirá su financiación por parte del gobierno. Con una mayor presión que probablemente recaiga sobre la financiación de la investigación, por parte de fuentes públicas, benéficas y comerciales, las universidades, en general, se enfrentarán a importantes desafíos financieros en el futuro. Para compensar la menor financiación gubernamental, las instituciones de educación superior podrían, como medida de ahorro de costos, estancar e incluso disminuir el número de puestos permanentes a tiempo completo $\mathrm{y}$ cambiar a puestos ocasionales o por contrato. Cambiar un puesto permanente a una modalidad contractual será 
A study conducted in $2015^{1}$ showed that $40 \%$ of the academic staff at the University of Cuenca is tenure, varying between 20 (Faculty of Hospitality) and 65\% (Faculty of Odontology). The remaining academic staff, on average $60 \%$ is casual or contracted, possessing a contract varying in duration from one to several semesters. It will be worthwhile following up in the near future how the ratio of tenure positions in the higher education system will evolve. A similar study in Australia highlights that $60 \%$ of the teaching staff in higher education institutions are contracted or casual, and the percent is increasing. It is estimated that the higher education sector in Australia is the third largest employer of casual staff, and it is expected that the budget cuts following the Covid-19 pandemic will further increase the fraction of casual academics. The main rationale behind the evolution from tenure to contractual academics is cost-saving and flexibility in managing staff. Similarly, contractual and part-time lecturers form a substantial chunk of the workforce in India's higher education sector.

Casualization of academics in higher education is not new and is typical in this sector. The road to a tenure full-time academic position is traditionally long, given that after graduation often follows specialization and/or the conduct of a doctoral study, sometimes even followed by a postdoc. Due to the limited number of permanent positions the requirements to be appointed are high and involve possessing in addition to a Ph.D., a record of published research, the ability to attract grant funding, academic visibility, and teaching excellence. The positions prior to a tenure position are in general casual or by contract. Whereas a step-wise procedure from graduation to fulltime tenure seems to be the most logic, in practice the contractual situation prior to the appointment might presents many disadvantages.

Contract and casual positions are often constrained by poor pay, uncertainty, and various forms of exploitation. The job is mostly focused on teaching, is part-time leaving little room for other activities such as specialization, research, or services in the context of the teaching assignment. Due to the uncertainty associated with the job, those in this position fail to fully identify themselves with the institution. Job insecurity is often associated with frustration and adverse work attitudes, affecting the teaching quality for which they are hired. Being in this position makes it not easy to participate in research, even if research in the institution is being undertaken, and get research papers published, a necessary requirement for climbing up the academic career ladder. The meager wages of part-time jobs have often other social impacts such as health, marriage, family, and other aspects, and whenever possible another part-time job is taken up outside of the teaching hours. It is evident that under those circumstances casualization negatively affects teaching quality, being generally the primary task of the part-time teaching academics. Their task is to impart knowledge to students, it is to equip the new generation with relevant skills in the open labor market, making the students upwardly mobile against the socio-economic challenges of the 21 st century. Several studies have given evidence that the insecure working conditions of the casual and part-time contracted academics works against achieving

${ }^{1}$ Feyen, J. (2015). Linking teaching and research to enhance student learning and scholarly activities at the University of jurídicamente difícil, probablemente imposible. Pero no es improbable que cuando los profesores a tiempo completo se jubilen, las vacantes se cubran con un puesto eventual o por contrato. Así, es de esperar que en los próximos años disminuya el número de puestos permanentes en la educación superior.

Un estudio realizado en $2015^{1}$ mostró que el $40 \%$ del personal académico de la Universidad de Cuenca es titular, variando entre el 20 (Facultad de Hotelería) y el 65\% (Facultad de Odontología). El resto del personal académico, en promedio un $60 \%$, es eventual o contratado, poseyendo un contrato que varía en duración de uno a varios semestres. En un futuro próximo, valdrá la pena hacer un seguimiento de cómo evolucionará la proporción de puestos permanentes en el sistema de educación superior. Un estudio similar en Australia destaca que el $60 \%$ del personal docente de las instituciones de educación superior es contratado o eventual, y el porcentaje va en aumento. Se estima que el sector de la educación superior en Australia es el tercer mayor empleador de personal ocasional, y se espera que los recortes presupuestarios posteriores a la pandemia Covid19 aumenten aún más la fracción de académicos ocasionales. La principal lógica de una evolución de académicos titulares a contratados es el ahorro de costos y la flexibilidad en la gestión del personal. De manera similar, los profesores contratados y a tiempo parcial constituyen una parte sustancial de la fuerza laboral en el sector de educación superior de la India.

La casualización de los académicos en la educación superior no es nueva y más bien es típica de este sector. El camino hacia un puesto académico permanente a tiempo completo es tradicionalmente largo, dado que después de la graduación a menudo sigue la especialización y/o la realización de un estudio de doctorado, a veces incluso seguido de un posdoctorado. Debido al número limitado de puestos permanentes, los requisitos para un nombramiento son altos e implican poseer, además de un doctorado, un historial de investigación publicada, la capacidad de atraer fondos de subvenciones, visibilidad académica y excelencia docente. Los puestos previos a un puesto permanente son en general casuales o por contrato. Aun cuando la transición desde la graduación hacia una titularidad a tiempo completo parecería ser un proceso lógico y ordenado, la situación contractual previa al nombramiento permanente puede presentar muchas desventajas.

Los puestos de contrato y eventuales a menudo están limitados por salarios bajos, incertidumbre y diversas formas de explotación. El trabajo se centra principalmente en la docencia, y aun cuando es a tiempo parcial, deja poco espacio para otras actividades como la especialización, la investigación y otros servicios en el contexto de la tarea docente. Debido a la incertidumbre asociada con el trabajo, quienes ocupan este puesto no se identifican plenamente con la institución. La inseguridad laboral se asocia a menudo con frustración y actitudes laborales adversas, que afectan la calidad de la enseñanza para la que son contratados. Estar en esta posición hace que no sea fácil participar en investigación, incluso si esta actividad se desarrolla en la institución, o publicar 
excellence in teaching. That not much is undertaken to improve the contractual situation of casual and part-time contracted lecturers is due to the fact that neither the academic institutions nor the lecturers concerned possess effective instruments to change the situation. The lecturers most likely agree with the insecure contract situation and working conditions because it is better than to be unemployed, while the institutions are likely restrained in offering tenure positions by budget restrictions and the fear of losing flexibility.

Casual and part-time teachers are an integral part of the higher education system and it is to be expected that Covid-19 will lead to an expansion of this workforce in the public and private universities. In fact, not all academic personnel at a higher education institute can be tenure, which is financially not feasible and probably not workable. To provide quality teaching for students' learning experience and the formation of knowledgeable and skilled graduates who can meet the workforce needs of the future, institutions need a cohort of academic staff with different capacities and ranks, whereby full-time tenure professor is the highest rank, and instructors, teaching and research assistants, non-tenure-track positions, the lowest rank. The latter group, depending on the situation, might have the opportunity to pursue in parallel to the teaching job the doctoral degree and obtain the non-tenure position of lecturer.

The position of assistant professor is in many countries the usual entry-level rank for faculty on the tenure track. It is unthinkable that everyone starting at the lowest rank ends up as a full professor, only those that meet the professional criteria and win the competition when there is a vacancy will be appointed. Here, the quality of the selection committee is of great importance, they must possess the skills to select the most qualified and promising candidate for the vacant position. It is neither a shame nor a handicap not obtaining a tenure position after a given period of contract service, given the institution allows besides the job to qualify further professionally and in entrepreneurial skills. The conditions for making temporary contracts viable for the persons in question are that the duration of these contracts is limited in time, guarantees a reasonable income, and allows them to further develop their skills in preparation for a career in the public or private sector. The public and private sector to be able of coping with the challenges of the 21 st century is more and more in need of Ph.D.-graduates with experience. It is unthinkable, offering for a long period, year after year, staff temporary contracts. This will not only harm the person in question but also the services the person will be offering to the institution. Institutions ought to have a clear and transparent personnel policy that stimulates the commitment of the tenure and non-tenure staff since a motivated and qualified staff is the first requisite to maintain and enhance the teaching and research performance of the university. When recruiting graduates, universities should provide candidates a clear picture of the job conditions and possibilities so that he/she during the contractual period of reasonable duration can prepare either for a career within or outside the institution. trabajos de investigación, un requisito necesario para ascender en la escala de la carrera académica. Los bajos sueldos de los trabajos a tiempo parcial suelen tener otros impactos sociales como la salud, el matrimonio, la familia y otros aspectos, por lo que siempre que es posible se toma otro trabajo a tiempo parcial fuera del horario de clases. Es evidente que en esas circunstancias la casualización afecta negativamente a la calidad de la enseñanza, siendo generalmente esta la tarea principal de los docentes a tiempo parcial. Su tarea es impartir conocimientos a los estudiantes, equipar a la nueva generación con habilidades relevantes en el mercado laboral abierto, haciendo que los estudiantes tengan una movilidad ascendente frente a los desafíos socioeconómicos del siglo XXI. Varios estudios han evidenciado que las condiciones de trabajo inseguras de los académicos ocasionales o contratados a tiempo parcial van en contra de la excelencia en la enseñanza. El hecho de que no se emprenda mucho para mejorar la situación contractual de este tipo de docentes se debe a que tanto las instituciones académicas como los docentes involucrados tienen escasos instrumentos para cambiar esta situación. Lo más probable es que los docentes estén de acuerdo con la insegura situación del contrato y las condiciones de trabajo porque esto es mejor que estar desempleado, mientras que las instituciones probablemente estén restringidas a la hora de ofrecer puestos permanentes debido a límites presupuestarios y al temor de perder flexibilidad.

Los docentes ocasionales son una parte integral del sistema de educación superior y se espera que la Covid-19 conduzca a una expansión de esta fuerza laboral en las universidades públicas y privadas. De hecho, no todo el personal académico de un instituto de educación superior puede ser titular, financieramente esto no es viable. Para proporcionar una enseñanza de calidad a los estudiantes y así formar graduados con conocimientos y habilidades que puedan satisfacer las necesidades de la fuerza laboral del futuro, las instituciones necesitan una cohorte de personal académico con diferentes capacidades y rangos, donde lógicamente el profesor titular a tiempo completo es el rango más alto, mientras que instructores, ayudantes de cátedra e investigación, aquellos puestos no permanentes, estén el rango más bajo. Este último grupo, dependiendo de la situación, podría tener la oportunidad de, paralelamente a sus actividades académicas, obtener el título de doctor y así optar por un puesto no permanente en la docencia.

En muchos países, el puesto de profesor asistente es habitualmente el rango o nivel de entrada para el profesorado en su carrera de titularidad. Es impensable que todo el que comience en el rango más bajo termine como profesor titular principal, solo lo consiguen aquellos que cumplen con los criterios profesionales y ganen el concurso cuando haya una vacante. Aquí, la calidad del comité de selección es de gran importancia, deben poseer las habilidades para seleccionar al candidato más calificado y prometedor para el puesto vacante. No es una vergüenza ni una desventaja no obtener un puesto permanente después de un período determinado de contrato de servicios, dado que la institución permite, además del trabajo, obtener mayor capacitación profesional y de emprendimiento. Las condiciones para que los contratos temporales sean viables para las personas en cuestión son que, a pesar de la limitada duración de estos, garanticen unos ingresos razonables y les permitan 
Casual and contractual labor will exist forever in society and higher education, and rather increase than decrease. To assure that the non-tenure juniors in higher education produce inclusive and quality education and research it is essential that the institutions provide the working conditions so that those employees remain motivated. Whereas an annually renewable contract might be normal in the initial phase of an academic career when with time not integrated into the tenure academic community, it might be more beneficial for the person involved to move to the public or private sector. desarrollar aún más sus habilidades en preparación para una carrera en el sector público o privado. El sector público y privado para poder hacer frente a los desafíos del siglo XXI necesita cada vez más de PhDs con experiencia. Es impensable ofrecer durante un largo período, año tras año, contratos temporales de personal. Esto no solo dañará a la persona en cuestión, sino también los servicios que la persona ofrece a la institución. Las instituciones deben contar con una política de personal clara y transparente que estimule el compromiso del personal titular y no titular, ya que un personal motivado y calificado es el primer requisito para mantener y mejorar el desempeño docente e investigador de la universidad. Al contratar a los graduados, las universidades deben proporcionar a los candidatos una imagen clara de las condiciones y posibilidades del trabajo para que, durante un período contractual de duración razonable, puedan prepararse para una carrera dentro o fuera de la institución.

La mano de obra ocasional y contractual existirá para siempre en la sociedad y en la educación superior, y más bien aumentará que disminuirá. Para asegurar que los jóvenes no titulares en la educación superior produzcan una educación e investigación inclusivas y de calidad, es esencial que las instituciones brinden las condiciones de trabajo necesarias para que esos empleados permanezcan motivados. Aun cuando un contrato anual podría ser normal en la fase inicial de una carrera académica, si la transición hacia una posición permanente tarda o está fuera de la vista, podría ser más beneficioso para la persona involucrada pasar a otra institución del sector público o privado. 